\title{
Environmental Criminality in Greece and Cyprus: Towards a Critical Green Criminology of the Eastern Mediterranean
}

\author{
Aimilia Voulvouli \\ Department of Sociology Fatih University 34500 Büyükçekmece, Istanbul \\ *Corresponding Author: aimilia.voulvouli@fatih.edu.tr
}

Copyright (C) 2013 Horizon Research Publishing All rights reserved

\begin{abstract}
Several studies suggest that both in Greece and Cyprus, environmental violations are being publicly discussed and defined by active citizens members of Environmental Non-Governmental Organisations (ENGOs) who demand the protection of the environment. These actors of civil society demand and often achieve visibility from the central policy making. Given the above, the present text attempts to propose certain points that could contribute towards the establishment of a Critical Green Criminology by taking into consideration bottom-up perspectives of environmental crime. By studying perspectives, representations and demands of environmental NGOs concerning environmental criminality, through the prism of environmentalism as a cultural perspective, the present article constitutes a proposal for a green criminology which will focus on the invisible - from formal social control environmental violations, as these are defined by active citizens and environmental organisations.
\end{abstract}

Keywords Greece, Cyprus, Environmental Criminality, Critical Green Criminology, ENGOs

\section{Introduction}

Last February six big wild predatory birds and two wild horses were found dead by the Nestos straits in northern Greece which is characterised as an area protected by Natura 2000 network. Ever since, the managing institution of the protected area along with environmental non-governmental organisations (ENGOs) is working with the local authorities hand-in-hand trying to locate the person(s) behind this killings [50]. This is one of many examples of cooperation between ENGOs and authorities in Greece, aiming at environmental (flora and fauna) protection. Nevertheless, environmental degradation is hardly decreasing and despite such efforts environmental crimes and offences are often overlooked [38]. In legal terms environmental crime is defined as illegal acts which directly harm the environment
[4]. Such a broad definition gives room to a wide range of interpretation and this is probably why, environmental legislation in countries such as Greece and the Republic of Cyprus is unclear as far as environmental crimes are concerned in the sense that "environmental goods and their violations are not located in specific decrees such as in the case of other goods but in various - mainly civil code decisions - and the European Law" [17 p.272]. At the same time many environmental crimes are not included in the official statistics despite the harmful effects that have on society [38]. Their effects even if they might not be, for various reasons, visible by law, they are noticed by local societies that suffer from them and consequently by environmental organisations.

Given the above, the present chapter attempts to propose certain points that could contribute towards the establishment of a Critical Green Criminology by taking into consideration bottom-up perspectives of environmental crime. By studying perspectives, representations and demands of environmental NGOs concerning environmental criminality, through the prism of environmentalism as a cultural perspective, this article attempts to propose a green cgriminology which will focus on the invisible - by formal social control - environmental violations, as these are defined by active citizens and environmental organisations.

\section{The Environmental Issue}

From Malthus' Essay on the Principle of Population (1798) to the 1972 volume entitled Limits to Growth which was commissioned by the Club of Rome ${ }^{1}$ there has been an increasing realisation that environmental resources are not endless. Ever since, environmental protection, sustainability,

\footnotetext{
1 The Club of Rome was founded in 1968 and constitutes a think tank dealing with various international policy issues. In 1972 published a report - which proved quite influencial - concerning the environment entitled The Limits to Growth discussing the risks that un-wise development has on the environment.
} 
sustainable development, biodiversity and conservation are some of the terms which have been referring to the environment and nowadays are very often encountered in newspapers, magazines, tourist guides, policy reports, academic texts and so on. Environmental organisations, governments, religious organisations, media, and people in private conversations often discuss environmental degradation and the need to put an end to it. This recognition of environmental degradation is expressed in many ways: through support for organisations dedicated to environmental protection, through government policies aimed at decreasing pollution or conserving wildlife, through 'green' political parties, through demands for changes in land use [27 p. 27, See also 28].

McCormick [24 p.xi] mentions that environmentalism generated new bodies of law, hatched new political parties, encouraged rethinking of economic and social priorities, and became a central issue in international relations. Thus in 1972 we have the first international conference on environmental issues namely the United Nations Conference on the Human Environment held in Stockholm. The 1992 Rio Summit, which until then was the biggest international conference on environmental issues discussed in brief: global warming, biodiversity, sustainable development, the right to development for the less developed countries and forestry. The emphasis of the Rio Summit was on the global character of environmental problems and the need for a global attempt to face such problems, even though attempts of international cooperation had been made before [44]. In 1997 we have the Earth Summit +5 which took place in New York City. The purpose of the summit was "to review and accelerate the implementation of Agenda 21 and other agreements made in Rio. Although there had been some successes since the Earth Summit 1992, members who met in New York were frustrated with degrading environmental conditions and rising levels of poverty worldwide. Leaders recommitted to the goals of Agenda 21, and it was agreed that considerable work was yet to be done, especially to address the effects of climate change" [46].

The first decade of the $21^{\text {st }}$ century was inaugurated by the 2002 Earth Summit, the World Summit on Sustainable Development (WSSD) which was held in Johannesburg. The meeting was held to discuss sustainable development and built on the declarations of Stockholm and Rio. According to the declaration of this Summit, the participants agreed on advancing and strengthening the interdependent and mutually reinforcing pillars of sustainable development, economic development, social development and environmental protection at the local, national, regional and global levels. It was decided that the rich diversity of the planet would be used for building constructive partnerships for change and for the achievement of the common goal of sustainable development. Finally, it was agreed that in order for the goals of sustainable development to be achieved, more effective, democratic and accountable international and multilateral institutions are needed.

The 2005 World Summit reaffirmed the commitment "to achieve the goal of sustainable development, including through the implementation of Agenda $21^{2}$ and the Johannesburg Plan of Implementation". The participants agreed on "undertaking concrete actions and measures at all levels and to enhancing international cooperation, taking into account the Rio principles. These efforts will also promote the integration of the three components of sustainable development - economic development, social development and environmental protection - as interdependent and mutually reinforcing pillars. Poverty eradication, changing unsustainable patterns of production and consumption and protecting and managing the natural resource base of economic and social development are overarching objectives of and essential requirements for sustainable development ${ }^{3 "}$. The 2010 United Nations Climate Change Conference was held in Cancún Mexico, while a few days ago (20-22 June 2012) the Earth Summit 2012 - Rio +20 was held in Rio de Janeiro. The outcome of the summit was the Rio +20 document in which there is the conclusion that there is a commitment to the 1972 Stockholm Declaration as well as the 1992 Rio declaration on Environment and Development and Agenda 21 [51].

Nevertheless the rates of environmental deterioration are not dropping. Inspite of the above efforts environmental crimes and offences are often overlooked [38]. Specifically in Greece, on which this chapter partly focuses on, environmental criminality has been mainly instigated by sensitive to such issues citizens and organisations (either formally or ad hoc formed) who managed to make the issue visible in institutional level [17]. Several studies suggest that in both Greece and Cyprus, environmental violations are being publicly discussed and defined by active citizens members of Environmental Non-Governmental Organisations (ENGOs) who demand the protection of the environment $[2,6,7,20,39]$. These actors of civil society demand and often achieve visibility from the central policy making justifying in this way the claim of Wapner [43 p.153] that "actions taking place in the civil society realm have consequences on the state realm and vice versa". Consequently, environmental organisations, which are considered as constitutive parts of civil society influence state policies. In this sense, it would be interesting to examine the ways this interaction takes place.

\footnotetext{
2 Agenda 21 is the action plan of the United Nations concerning sustainable development. It was produced after the Rio Summit and it constitutes one of the first texts focusing on the global character of the environmental degradation and the need for global management of it.

${ }^{3}$ The 2005 World Summit was held in New York on 14-16 September 2005. This summit was a follow-up summit meeting to the United Nations' 2000 Millennium Summit, which led to the Millennium Declaration of the Millennium Development Goals (MDGs). The summit was described as "a once-in-a-generation opportunity to take bold decisions in the areas of development, security, human rights and reform of the United Nations".
} 


\section{Green Criminoloy}

Over the last twenty years, criminologists have shifted their focus on 'green crimes' $[8,9,17,21,22,36,38]$. In this framework there has been much discussion on environmental crimes and the field of green criminology has been gaining ground as a distinctive field in the discipline of criminology. According to Carabine et al [8 p.28] green criminology should a) focus on the nature and the characteristics of environmental crimes b) suggest ways of confronting it through legislation and political power c) associate it with social inequalities d) focus on the role of environmental social movements in the social changes that are required in order to deal with green crimes. Those are:

a) Illegal or harmful conduct as far as the natural environment is concerned [ $22 \mathrm{p.} \mathrm{46] \text {. }}$

c) Actions that purposely or eventually cause damage to eco- and bio-systems aiming at serving individual or corprorate interests [ 9 p. 26].

According to the United Nations Interregional Crime and Justice Institute (UNICRI) as environmental crimes can be considered the illegal dumping of house waste, the circulation and discarding of toxic and nuclear waste, deforestation, environmental contamination, illegal trading of material that decrease the quantity of ozone in the atmosphere, illegal hunting and trading of animal species under the threat of extinction [36 p. $316-19]$. All the above categories of environmental crimes are not considered stricto senso as such [38 p. 36]. As very well Tsouramanis [38] describes the emission of carbon dioxide by a private vehicle is harmful only when it is added to that of other vehicles. In this sense, should carbon dioxide emission of one vehicle be considered criminal? The fact that traditionally environmental offences are committed by upper class groups (white collar crimes and particularly business or corporate crimes) and that lower-classes are considered the bearers of such offences is another aspect discussed by green criminologists [31 p. 205] and this is another issue suggesting that environmental criminality is subject to interpretation which in turn, means that green criminology should factor in a variety of criteria namely political, economic, legislative and - as suggested in the following section - cultural.

These aspects should be taken under consideration not only because any sociological study of such issues benefits from a multivariate analysis but also - and most importantly for this case - because many crimes committed by groups in power that have influence in government and legislative mechanisms are being overlooked and thus belong to the so called dark figure of criminality, that is crimes that do not appear in official statistics. This fact creates the false impression that individual crimes are higher in rates than corporate crimes even if the latter are in most cases more harmful than the former.

However, it seems that the dark figure of criminality is hardly dark for committed active civil society environmental groups. All over the world there are thousands of examples of environmental groups that discover and uncover the millions of environmental offences and struggle for their correction. The number of environmental organisations existing world-wide is more than 100,000 [43]. This number includes not only institutionalised environmental groups but also non-institutionalised environmental movements, which are "broad networks of people and organisations, engaged in collective action in the pursuit of environmental benefits" [32 p. 2]. Branches of the environmental movement come into conflict with and challenge political and economic power-holders over issues of ecosystem use [20]. For example the Wise Use Movement in North America, that stresses the neglect of local communities by big environmental organisations [23] and local environmental protests $[1-3,5,10,14,15,18,25,26,39,40,42]$ many of which articulate environmentalism with issues of ethnic and religious identities [14], democracy [2, 29, 39] and human rights [29, 33].

Given the above, environmentalism can be defined as the promotion of values, attitudes and policies aimed at reaching an accommodation between human needs and the limits of the natural environment [24 p. xv]. Even if it started as a form of scientific criticism it developed into a wider social movement [16] that goes beyond the strict environmental definition of the issues at stake [20]. In this sense, 'Green' criminology should, amongst others, take into consideration the role and the influence of environmental movements in combating environmental crime [ 8 p. 8]. Such a claim proves quite accurate for two reasons: Firstly, because the history of environmentalism demonstrates the important role of environmental movements in environmental protection. Secondly, because in the work at hand, criminology is considered a discipline in the context of which the definition of crime includes not only legal but also social, political and cultural aspects [13]. In this direction, following Salamon et al [34 p. 2], who claim that "the rise of the civil society sector may, in fact, prove to be as significant a development of the late twentieth and early twenty-first centuries as the rise of the nation-state was of the late nineteenth and early twentieth centuries", as it is able to counterbalance the statist dominance [12], the particular research scheme will take into account perceptions and claims of civil society actors such as ENGOs not only because historically, as mentioned above they have influenced environmental policy but also because their perceptions on what constitutes an environmental violation could prove considerably useful in the formulation of laws that concern environmental protection.

\subsection{Green Criminal Policy and Environmental Organisations in Greece and Cyprus}

In Greece, environmental legislation is divided in seven topics: air pollution, water-resource management, solid waste management, energy, noise pollution, environmental impact assessment and protected areas [45]. The Law $1650 / 1986$ in particular, forecasts penal as well as administrative sanctions to individuals or companies that 
cause environmental deterioration. Nevertheless, the criminalization of violations proves quite tricky due to the vagueness of the definition of environmental crime [38]. According to Kallintzaki [17 p. 272-273] "the characteristic [of the environment] as 'good' is fluidity. It does not have a definite character as far as approaches on the definition of legal good are concerned... it is generally perceived as quality of life attached to a great extent of vagueness. In this sense, it could be anything from services to eating habits".

In the Republic of Cyprus environmental policy is regulated by the Cyprus government's Ministry of Agriculture, Natural Resources and Environment (MANRE). MANRE is specifically responsible for: (1) carrying out environmental impact assessments, (2) drafting laws on pollution and waste management, (3) creating environmental awareness and training and (4) implementing international conventions and European Union (EU) legislation on the environment. These responsibilities are carried out primarily by the Environment Service of MANRE. Other departments within MANRE that contribute to environmental regulation include the Water Development Department, the Department of Agriculture, the Department of Fisheries and Marine Resources, the Department of Forests, and the Department of Veterinary Service. Many other government departments in Cyprus contribute directly or indirectly to environmental management, including the Ministry of the Interior's Department of Town Planning and Housing (the planning authority of the government and in charge of imposing environmental conditions during the permit process) and the Ministry of Finance's Planning Bureau (in charge of allocating resources for infrastructure needed to comply with environmental protection). Nevertheless, despite the sufficient legislation, according to the European Commission Cyprus along with Italy and Malta are amongst the worst at enforcing environmental law [47]. For example despite the importance of the Habitats and Birds Directives for the protection of biodiversity in Cyprus, the extent to which they will regulate the environmental impact of industry on the island is not clear [48].

The gap between environmental legislation and its application is usually being filled by the actions of environmental organisations and campaigns [19, 29, 33]. Especially for Greece and Cyprus there are cases of environmental controversies that led to legal battles [39, 40]. Environmental organisations in both countries are active and well informed on environmental regulations.

There are more than 2,000 recorded environmental protests in Greece [20] and around 250 recorded environmental organisations [6]. Their character varies from local grassroots to national, international and transnational organisations. However, despite their different character all these campaigns and organisations have posed the environment as a social problem [35].

In the Republic of Cyprus there are dozens of environmental campaigns. The Cyprus Federation of Environmental and Ecological Organisations for example consists of 18 members [49] and it is certain that this number constitutes only a part of the total number of the organisations that exist on the island. According to the website of Charalambos Theopemptou, the Environment Commissioner of Cyprus and member of the Cyprus Green Party, the number of the Cypriot environmental organisations is 30 [52].

Having mentioned the above, the present work suggests that the study of the effect that this big number - considering the total population in both countries - of environmental organisations have, on policy making and especially on Green criminal policy is necessary in order to help towards the clarification of environmental legislation, using a bottom-up approach that sheds light to the dark figure of environmental criminality ${ }^{4}$.

\section{Conclusions: Towards a Critical Green Criminology}

A study like the one proposed above could shed light both into the dark figure of criminality as far as environmental violations are concerned in the framework of a critical view of green criminology. Such a view will be based on an analysis of crime as a phenomenon inherent in capitalist society [37]. Accordingly, environmental violations should be studied sociologically, taking into account the whole

4 The methodology adopted in this study will extend from quantitative to qualitative research techniques. As far quantitative data is concerned, there will be a recording of the active ENGOs in both countries. Then, a selection of these NGOs whose action is concerned mainly with notifying to the public environmental violations will be made. Finally, a collection of press articles as well as collection of data from their own (if they exist) websites concerning the activities of these organisations, will take place in order to be able to determine the extent of their repertoires of action and their actions concerning protests about what they perceive as environmental crimes. The selection of the most active organisations in Greece and Cyprus based on their activities relative to the topic of the study will be the final part of this phase of research. As soon as this phase is completed, quantitative approach will give its place to qualitative research. Following the theoretical background described briefly above, the qualitative part of the research will be focused on interviews which will take into account not only the perceptions concerning environmental crime but also wider perceptions on crime and environment, following the stance that environmentalism can be viewed as a type of cultural perspective, a particular way of understanding the world [28, See also 11]; a part of the way in which people understand the world and their place within it that belongs to the sphere that includes people's feelings, thoughts, interpretations, knowledge, ideology, values and so on (ibid.: 33). 
social context as shaped by inequalities in wealth and power stemming from class relations [13]. Such a study should revolve around social structure and the interactions between people and structures of power in the context of which deviance as a process takes places (ibid). In addition, the contradictions of crime as an inherent part of the whole phenomenon should be studied under the viewpoint of conflict which analyses crime as the product of criminalisation of those in power and hence winners of the social conflicts at the expense of the weak and hence losers. In this sense, critical green criminology should examine the ways in which certain environmental violations are vanished in the eyes of the formal social control while others are not; whose violations are considered as a crime and whose violations are not.

\section{REFERENCES}

[1] Arundhati, R. I aksìa tis zois. Psihoyos, Athens, 2000.

[2] Arsel, M. Risk Society at Europe's Periphery? The Case of the Bergama Resistance in Turkey. In: Gökşen et al (eds.) Integrating and Articulating Environments: A Challenge for Northern and Southern Europe. Swets and Zeitlinger, 2003.

[3] Arsel, M n.d. Transnational Advocacy Networks in the Mediterranean:The case of nuclear energy in Turkey.

[4] Banks, D., Davies, C., Gosling, J., Newman, J., Rice, M., Wadley, J., Walravens, F. Environmental Crime. A threat to our future. Environmental Investigation Agency 2008.

[5] Beşpınar-Ekici, U. F. and D. Gökalp Power Brokers, Local Beneficiaries and Empowering the Powerless: A Critical Assessment of the NGOs, Civil Society and Democracy in Turkey. Paper presented in the Graduate Student Conference. Institute for International and Regional Studies, Princeton University, 7-8 April 2006.

[6] Botetzagias I. 2007, Clinging on? The Cypriot Greens, Environmental Politics,Vol.16, No.1, 24-129.

[7] Botetzagias I. \& Karamichas J. 2009, Grassroots mobilisations against waste disposal sites in Greece, Environmental Politics, 18(6): 939-959.

[8] Carabine, E., P. Iganski, Lee, M., Plumme K., and N. South Criminology: A Sociological Introduction. Routledge, London, 2004.

[9] Clifford M., Environmental Crime Enforcement: Policy and Social Responsibility. Aspen, Gaithesburg, 1998.

[10] Cummings, B. Dam the rivers, damn the people. Development and resistance in Amazonian Brazil. Earthscan Publications Ltd., London, 1990.

[11] Einarsson, N. All animals are equal but some are cetaceans: conservation and culture conflict. In: Milton K (ed.) Environmentalism: The View form Anthropology. Routledge, London, New York, 1993.

[12] Gellner, E. Conditions of Liberty: Civil Society and Its Rivals. Penguin, London, 1994.
[13] Georgoulas, G. Radix of Radical Criminology - Hesiodos. In: S. Georgoulas (ed.) The Politics of Criminology. LIT Verlag, Berlin, 2012.

[14] Ignatow, G. 2005a From Science to Multiculturalism: Postmodern Trends in Environmental Organisations. Global Environmental Politics Vol. 5, No. 2, 88-113.

[15] Ignatow, G. 2005b 'Economic Dependency and Environmental Attitudes in Turkey'Environmental Politics Vol. 14, No. 5, 648-66.

[16] Jamison, A., R. Eyerman, Cramer, J. and J. Læssǿe The Making of the New Environmental Consciousness: A Comparative Study of the Environmental Movements in Sweden, Denmark and the Netherlands. Edinburgh University Press, Edinburgh, 1990.

[17] Kallintzaki, E. Egklimatologikès Òpsis ton Prosvolòn tou Perivàllontos. In: S. Georgoulas (ed.) I Egklimatologìa stin

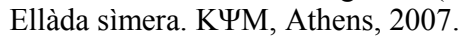

[18] Kenny, S. The Hindmarsh Island Bridge: Case-Implications for Native Title Paper presented at the AIC Native Title Conference, April 1998.

[19] KHRP, The Ilisu Dam: A Human Rights Disaster in the Making. November 1999.

[20] Kousis, M. Greece. In Rootes, C. (ed.) Environmental Protest in Western Europe. Oxford University Press, Oxford, 2004.

[21] Lynch, M. 1990 The greening of Criminology: a perspective for the 1990's. The Critical Criminologist Vol. 2, 1-5.

[22] McLaughlin, E. and Muncie, J. The Sage Dictionary of Criminology. Sage, London, 2006.

[23] McCarthy, J. Constraints and opportunities in adopting, adapting, and inventing. In: McAdam, D., J. D. McCarthy, Zald, N. M. (eds.) Comparative perspectives on social movements: Political opportunities, mobilizing structures, and cultural framings. Cambridge University Press, Cambridge, 1996.

[24] McCormick, J. The Global Environmental Movement. Wiley, Chichester, 1995.

[25] McCormick, S. 2006 The Brazilian Anti-dam Movement. Organization\&Environment Vol. 19, No 3, 321-346.

[26] McKay, G. Senseless Acts of Beauty: Cultures of Resistance. Verso, London 1996.

[27] Milton, K. Introduction: Environmentalism and anthropology. In: Milton K (ed.) Environmentalism: The View form Anthropology. Routledge, London, New York, 1993.

[28] Milton, K. 1996 Environmentalism and Cultural Theory: exploring the role of anthropology in environmental discourse. Routledge, London, New York, 1996.

[29] Öncü, A. and G. Koçan 2001 Political Identity and Citizenship Politics. Nationalism and Cosmopolitanism in the Bergama Movement in Turkey. New Perspectives on Turkey Vol. 26, $29-57$.

[30] Öncü, A. and G. Koçan Democratic Citizenship Movements in the Context of Multi-layered Governance: The Case of the Bergama Movement. Sabanc1 University and Bilkent 
University, 2002.

[31] Reiman, J. The rich get richer and the poor get prison Ideology, Class and Criminal Justice. Pearson, Boston, 2004.

[32] Rootes, C. Acting Globally, Thinking Locally? Prospects for a Global Environmental Movement. In: Rootes, C (ed.) Environmental Movements: Local, National and Global. Frank Cass, London, 1999.

[33] Sachs, A. What do human rights have to do with environmental protection? Everything. Paper prepared for the Local Libraries: Global Awareness Project, 1997.

[34] Salamon, L. M., S. W. Sokolowski and List, R. Global Civil Society: An Overview. The John Hopkins University, Baltimore, 2003.

[35] Serdedakis, N. and S. Alexandropoulos Greek Environmenalism: From the status nascendi of a movement to its integration. Paper presented at the ECPR workshop on Environmental Organisations. Copenhagen, April 2000.

[36] Soyland, S.Criminal Organisations and Crimes Against the Environment, Turin, UNICRI, 2000.

[37] Taylor, I.. Walton, P. and Young, J., The New Criminology: For a Social Theory of Deviance. Routledge and Kegan Paul, London, 1973.

[38] Tsouramanis, Ch. 2008 Egklìmata katà tou Perivàllontos: Egklimatologikì Proséggisi. Nèoi, Ėgklima ke Koinonìa Vol. 1, 33-41.

[39] Voulvouli, A. From Environmentalism to Transenvironment alism: The Ethnography of an Urban Protest in Modern Istanbul. Peter Lang Publications, Oxford, 2009.

[40] Voulvouli, A. 2010 Leftism, Secularism, Transnationalism and Localism: The Identities of an Urban Protest in Contemporary Istanbul. Ethnologia On-Line(http://www.soc ietyforethnology.gr/site/pdf/TheidentitiesofASG.pdf).

[41] Voulvouli, A. 2011 Grassroots Mobilisation in Turkey: The Transnational Character of Local Environmental Protests. International Journal of Academic Research Vol. 3, No. 1, $881-888$.

[42] Wall, D. Earth First! And the Anti-Roads Movement: Radical Environmentalism and Comparative Social Movements. Routledge, London, 1999.

[43] Wapner, P. K. Environmental Activism and World Civic Politics. State University of New York Press, New York, 1996.

[44] Yearly, S. Standing in for nature: the practicalities of environmental organisations' use of science. In: Milton K (ed.) Environmentalism: The View form Anthropology. Routledge, London, New York, 1993.

[45] Online available:http://www.ct.aegean.gr/people/pavlogeorg atos/el/gelen.html

[46] Online available:http://earthsummit.ca/about-earth-summit/e arth-summit-history/

[47] Online available: http://news.bbc.co.uk/2/hi/6344849.stm.

[48] Online available: http://biostrat.org/NR-B\&B_Cyprus.pd

[49] Online available: http://www.oikologiafeeo.org/
[50] Online available: http://reviews.in.gr/agro/environment/articl e/?aid=1231183378

[51] Online available: http://www.slideshare.net/uncsd2012/the-f uture-we-want-rio20-outcome-document

[52] Online available: http://theopemptou.blogspot.com/ 